\section{Original Research}

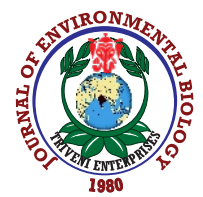

DOI : http://doi.org/10.22438/jeb/4(SI)/MS_1903
Journal Home page : www.jeb.co.in $\star$ E-mail : editor@jeb.co.in Journal of Environmental Biology

p-ISSN: 0254-8704 e-ISSN: 2394-0379 CODEN: JEBIDP

\title{
Ichthyofauna of Dampa Tiger Reserve Rivers, Mizoram, North-Eastern India
}

\author{
Lalramliana $^{1 *}$, M.C. Zirkunga' and S. Lalronunga ${ }^{2}$ \\ ${ }^{1}$ Department of Zoology, Pachhunga University College, , Aizawl-796 001, India \\ ${ }^{2}$ Systematics and Toxicology Laboratory, Department of Zoology, Mizoram University, Aizawl - 796 004, India \\ *Corresponding Author Email : Irl_zoo@yahoo.co.in
}

\section{Abstract}

Aim: The present study was undertaken to assess the fish biodiversity in buffer zone of rivers of the Dampa Tiger Reserve, Mizoram, India and to evaluate whether the protected river area provides some benefits to riverine fish biodiversity.

\begin{abstract}
Methodology: Surveys were conducted in different Rivers including the buffer zone of Dampa Tiger Reserve during the period of November, 2013 to May, 2014 and October, 2019. Fishes were caught using different fishing nets and gears. Collected fish specimens were identified to the lowest possible taxon using taxonomic keys. Specimens were deposited to the Pachhunga University College Museum of Fishes (PUCMF) and some specimens to Zoological Survey of India (ZSI) Kolkata. Shannon-Wiener diversity index was calculated.
\end{abstract}

Results: A total of 50 species belonging to 6 orders, 18 families and 34 genera were collected. The order Cypriniformes dominated the collections comprising $50 \%$ of the total fish species collected.

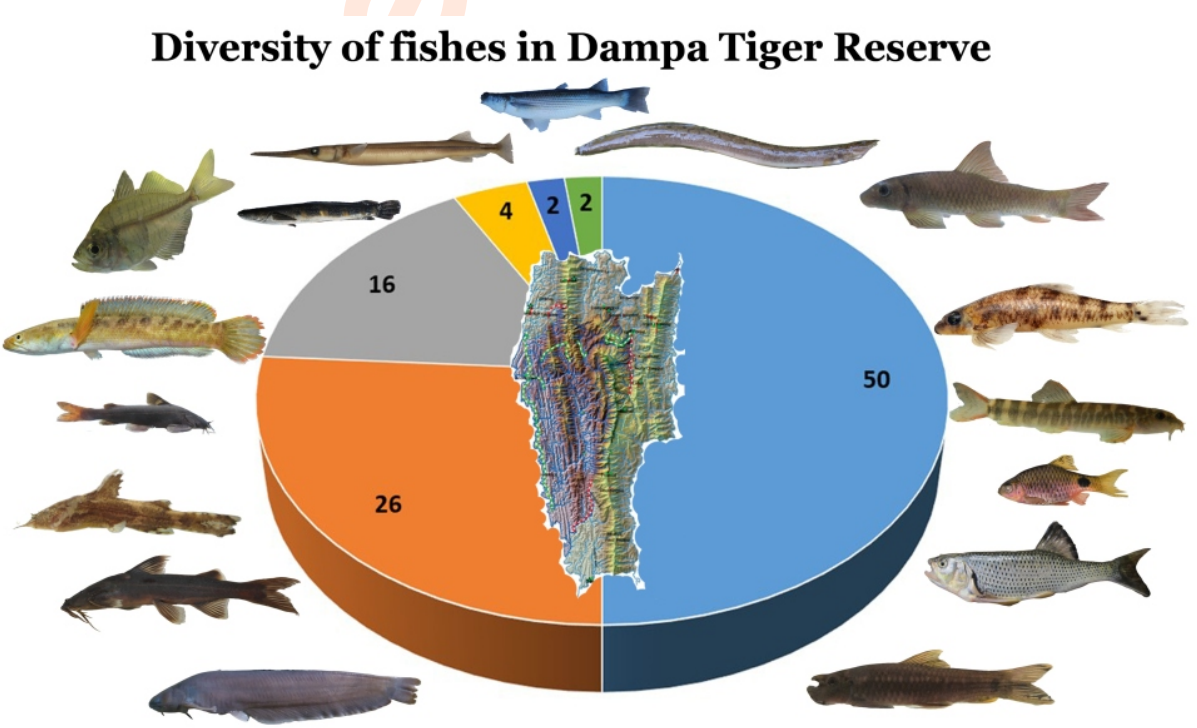
rhabdotus and Psilorhynchus rahmani; one new record from Mizoram viz., Dermogenys sp. and two new records from the Karnaphuli drainage viz., Garra nigricollis and Schistura paucireticulata. The result revealed high diversity of fish species with diversity index of 3.78 .

Interpretation: The high ichthyofaunal diversity was observed, in this study, revealed the importance of the Dampa Tiger Reserve. The protected area could be important for conservation and management of fish diversity in the region, especially for resident and threatened species.

Key words: Biodiversity hotspot, Conservation, Drainage system, New record

How to cite : Lalramliana, M.C. Zirkunga and S. Lalronunga: Ichthyofauna of Dampa Tiger Reserve Rivers, Mizoram, North-Eastern India. J. Environ. Biol., 41, 884-895 (2020). 


\section{Introduction}

With increasing in human population growth and expansion of land utilized for habitat and agricultural purposes, species are becoming extinct, making conservation of biodiversity a major challenge. The increasing loss of biodiversity is very challenging which requires the discovery and analysis of biodiversity at a greatly accelerated rate (Smith et al., 2003). The Dampa Tiger Reserve $\left(23^{\circ} 20^{\prime}\right.$ to $23^{\circ} 47^{\prime} \mathrm{N}$ and $92^{\circ} 15^{\prime}$ to $\left.92^{\circ} 30^{\prime} \mathrm{E}\right)$, the largest protected area in Mizoram, is situated in the western part of Mizoram (Mamit District), North-Eastern India covering an area of $500 \mathrm{sq} . \mathrm{km}$. The area is covered by tropical evergreen and semi-evergreen forest as well as tropical moist deciduous forest (Champion and Seth, 1968; Pawar and Birand, 2001). The area is drained with the Keisalam, Seling, Aivapui and Mar Rivers (Karnaphuli Drainage) including Teirei and Tut Rivers (Barak Drainage) at the buffer zone. The freshwater fauna of Mizoram, North-Eastern India is not only rich in diversity but also distinct from the mainland India and its adjacent countries. This is due to the presence of three independent major river drainage system which are not connected even in the flood plains viz., Barak drainage (Ganges-Brahmaputra basin), Karnaphuli drainage and Kaladan drainage system. Besides, rivers of the area are poorly explored because of difficult topography and lack of proper road connection.

Taxonomic survey and its documentation pertaining to Ichthyofauna of Mizoram is far from complete due to lack of extensive survey works. Moreover, no diversity studies have been conducted in Dampa Tiger Reserve, except some new fish species described (Lalronunga et al., 2013; Lalramliana et al., 2014; Lalhlimpuia et al., 2016) from the Reserve and its buffer zone. The aim of this study was to assess fish diversity within and the buffer zone of the Dampa Tiger Reserve in order to provide reference information as a baseline for further conservation of the area.

\section{Materials and Methods}

Extensive surveys were conducted in different Rivers including the buffer zone of Dampa Tiger Reserve (Aivapui, Keisalam, Seling, Mar Rivers of Karnaphuli Drainage and Teirei and Tut Rivers of Barak Drainage), during the period of November 2013 to May 2014 and October 2019. Fishes were caught using different fishing nets and gears. Specimens were fixed in $10 \%$ formalin and later preserved in $70 \%$ ethanol. The fishes were measured and identified following taxonomic keys (Menon, 1964; Kottelat, 1990; Jayaram, 1999; 2006). Identification was done to the lowest possible taxon, counts and measurements were made on the left side of specimens whenever possible. Osteological studies were done following the procedure of Taylor \& Van Dyke (1985). Specimens were deposited to the Pachhunga University College Museum of Fishes (PUCMF) and some specimens to Zoological Survey of India (ZSI) Kolkata.

Shannon-Wiener diversity index was used to describe the fish species diversity using the formula:

$$
H^{\prime}=-\sum_{i=1}^{R} p i \ln p i
$$

where, pi is the proportion of individuals belonging to the $i^{\text {th }}$ species.

\section{Results and Discussion}

The study resulted in the documentation (including undetermined species) of 50 species belonging to 18 families and 6 orders. The calculated Shannon index value is 3.78 , revealing the high diversity along with the richness and evenness of fish species in the Dampa Tiger Reserve.

\section{Species Account ORDER: BELONIFORMES \\ Family: Belonidae \\ Xenentodon cancila (Hamilton, 1822) \\ Common Name: Freshwater gar fish/Asian needle fish \\ Local Name: Nghafunglawr}

Remarks: It is characterized by their relatively large and heavyset of jaws, length of upper jaw fits 2.6-3.2 times in body length measured from anterior margin of orbit to end of hypural plate, 9-21 enlarged teeth in upper jaw, dorsal-fin origin usually anterior to a vertical through anal-fin origin, heavy-bodied and reaching 40 $\mathrm{cm}$ TL

\section{Family: Zenarchopteridae}

\section{Dermogenys sp.}

Common Name:Silverhalfbeak/pygmy halfbeak/wrestling halfbeak Local Name: Nghafunglawrte

Remarks: Viviparous; slender body. Upper jaw longer than wide; biserial or tri-serial conical oral teeth; teeth on lower jaw not extending over anterior margin of upper jaw.

\section{ORDER: CYPRINIFORMES \\ Family: Balitoridae \\ Balitora brucei Gray, 1830}

Common Name: Gray's stone loach

Local Name: Nghalungbet/Nghapawmrem

Remarks: Dorsal fin originates opposite of ventral, head depressed, mouth ventral, eye small, brown blotches dorsally (8-10) and laterally, dirty yellowish ventrally. Lateral line complete. Pectoral and ventral fin placed horizontally with brown tinge, pectoral broader than ventral. Lower lobe of caudal fin longer than upper with black tinge. Skin rough to touch with minute tubercles

\author{
Family: Cobitidae \\ Lepidocephalichthys berdmorei(Blyth, 1860) \\ Common Name: Spiny loach \\ Local Name: Nghachik
}


Remarks: Truncated or rounded caudal fin; scales absent on top of head; anterior rostral barbels long, extending past anterior nostril. Irregular dark spots on side; three to six dark bars on caudal fin; lamina circularis composed of fused and thickened seventh and eighth pectoral rays, forming long cylinder along edge of fin.

\section{Family: Cyprinidae \\ Amblypharyngodon mola (Hamilton, 1822) \\ Common Name: Mola carplet \\ Local Name: Mawka}

Remarks: Compressed and elongate bodied fish. Body color silvery, light greenish on back, conspicuous lateral silvery band along the body. Black markings on the dorsal and anal fins. Caudal fin deeply forked; lobes pointed. Lateral line complete with 65-70 scale rows.

\section{Barilius bendelisis (Hamilton, 1807) \\ Common Name: Hamilton's Barila \\ Local Name: Lengphar zangchhah}

Remarks: Deep, compressed and elongate bodied fish, two pairs of barbel present. Dorsal fin entirely inserted in advance of anal fin. Lateral line complete with 39-42 scale rows. Body with 8-12 bluish vertical bars on the side of the body, 18-20 predorsal scales.

Devario aequipinnatus(McClelland, 1839)

Common Name: Giant danio

Local Name: Nghadawl

Remarks: Maxillary barbel present. P-stripe originating on lateral body surface anterior to dorsal-fin origin; P-1 stripe continuous or interrupted along anterior most portion only.

Danio dangila (Hamilton, 1822)

Common Name: Moustached danio

Local Name: Nghadawl de

Remarks: Two pairs of barbells, Maxillary barbels about double length of rostral barbels. Lateral line complete. Body striped with rows of dark rings with light centres on side of body, circumpeduncular scale rows 14 , infra-orbitals tubercles absent.

\section{Esomus danricus (Hamilton, 1822)}

Common Name: Flying barb

Local Name: Nghadungrin hmui hmul nei

Remarks: Body elongated, slim and compressed. Two pairs of barbels. Maxillary barbels long extending to middle of body, rostral barbel short. Lateral line incomplete. Lower jaw longer.

Garra aff. lissorhynchus (McClelland, 1842)

Common Name: Khasi Garra

Local Name: Nghazawngek
Remarks: A moderately sized Garra very similar to $G$. lissorhynchus. It possessed W-shaped broad band across the caudal fin, smooth snout, dorsal fin with 2 simple and $61 / 2$ branched rays; $31-32$ lateral line scales; $4 / 1 / 3$ scales in a transverse row; 14 predorsal scales; dorsal fin with transverse black bar. However, it is markedly differing from $G$. lissorhynchus in having (vs. lacking in $\mathrm{G}$. lissorhynchus) scales on the breast and belly.

\section{Garra dampaensis Lalronunga, Lalnuntluanga \& Lalramliana, 2013 \\ Common Name: Dampa Garra \\ Local Name: Dampa Nghazawngek}

Remarks: It is a new species recently described from Seling river of Dampa Tiger Reserve. It is characterized by no transverse groove and proboscis on the snout; tip of dorsal fin falcate; long axillary scale present at the base of pelvic fin, reaching the base of last pelvic fin ray; 27-29 lateral-line scales, 10-11 regularly arranged predorsal scales; W-shaped black band across the middle of caudal fin and presence of scales on the breast and belly.

\section{Garra manipurensis Vishwanath \& Sarojnalini, 1988 Common Name: Manipur Garra Local Name: Nghalim}

Remarks: No transverse groove and proboscis on the snout. Lateral line complete, with 30-32 scales. Circumpeduncular scale rows 16, predorsal scales 11-14. Chest and belly scaled; scales on chest sparse, under thick skin. Axillaryscale at base of pelvic fin present. Faint greyish stripe over lateral-line scales extending to median rays of caudal fin.

\section{Garra nigricollis Kullander \& Fang, 2004 \\ Common Name: - \\ Local Name: Nghalim}

Remarks: It possessed a smoothly rounded snout, rostral lobes present, proboscis absent, tubercles on anterior region of snout; predorsal, chest and abdomen scaled; two pairs of barbels, lateral line complete with 32-34 scale rows, circumpeduncular scale rows 16 . The most distinguishing characters being the presence of a black band across the posterior margin of the head, between left and right-side pectoral fin bases.

\section{Garrasp.}

Common Name:

Local Name: Nghalim hnarchat

Remarks: A species of Garra with transverse groove on the snout with many tubercles. Proboscis with no separate lobe. Dorsal fin with $81 / 2$ branched rays and 32-34 lateral line scales

\author{
Neolissochilus hexagonolepis (McClelland, 1839) \\ Common Name: Mahseer \\ Local Name: Nghahrah meidum
}



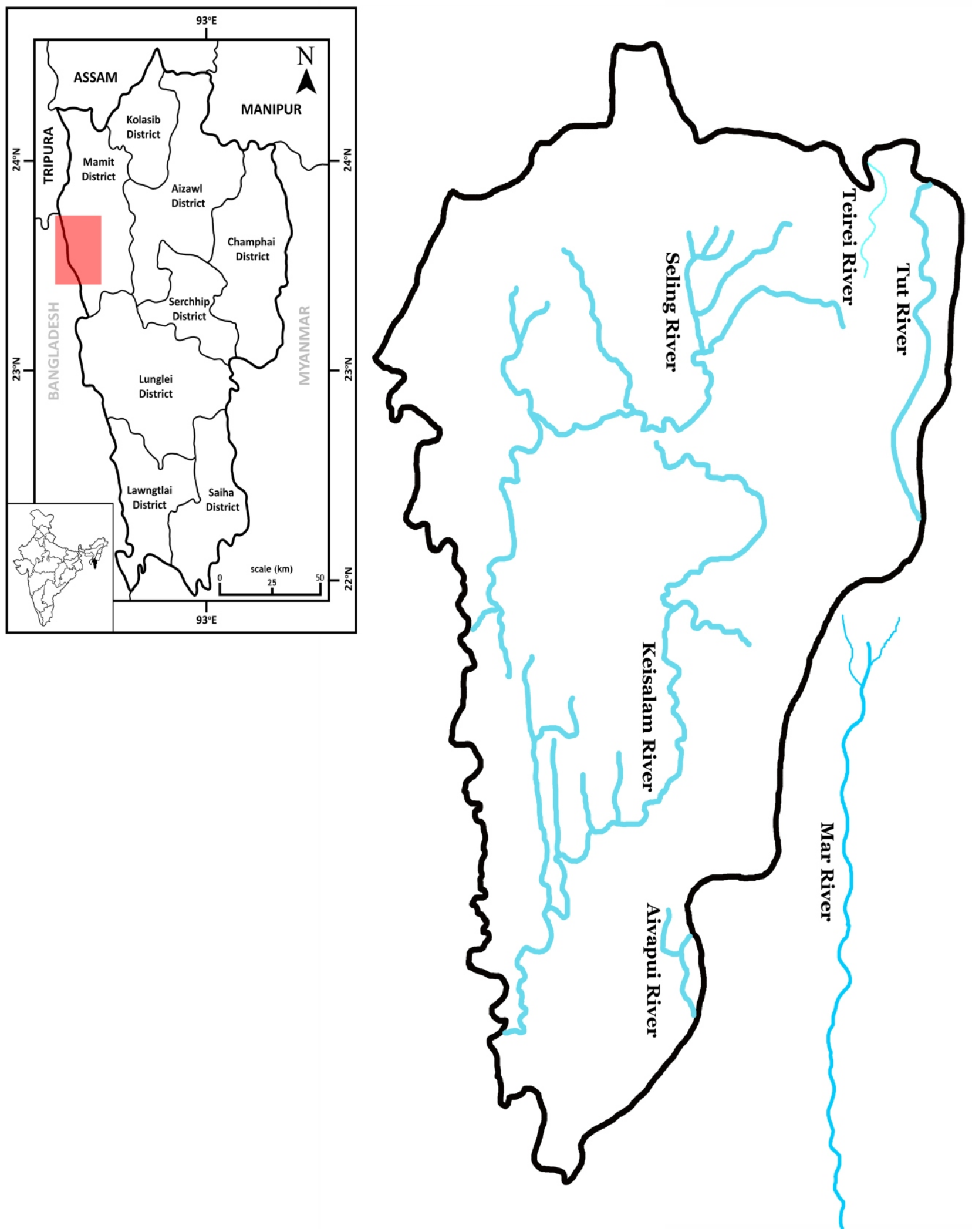

Fig. 1: Map of Dampa Tiger Reserve, Mizoram, North-Eastern India showing rivers. 

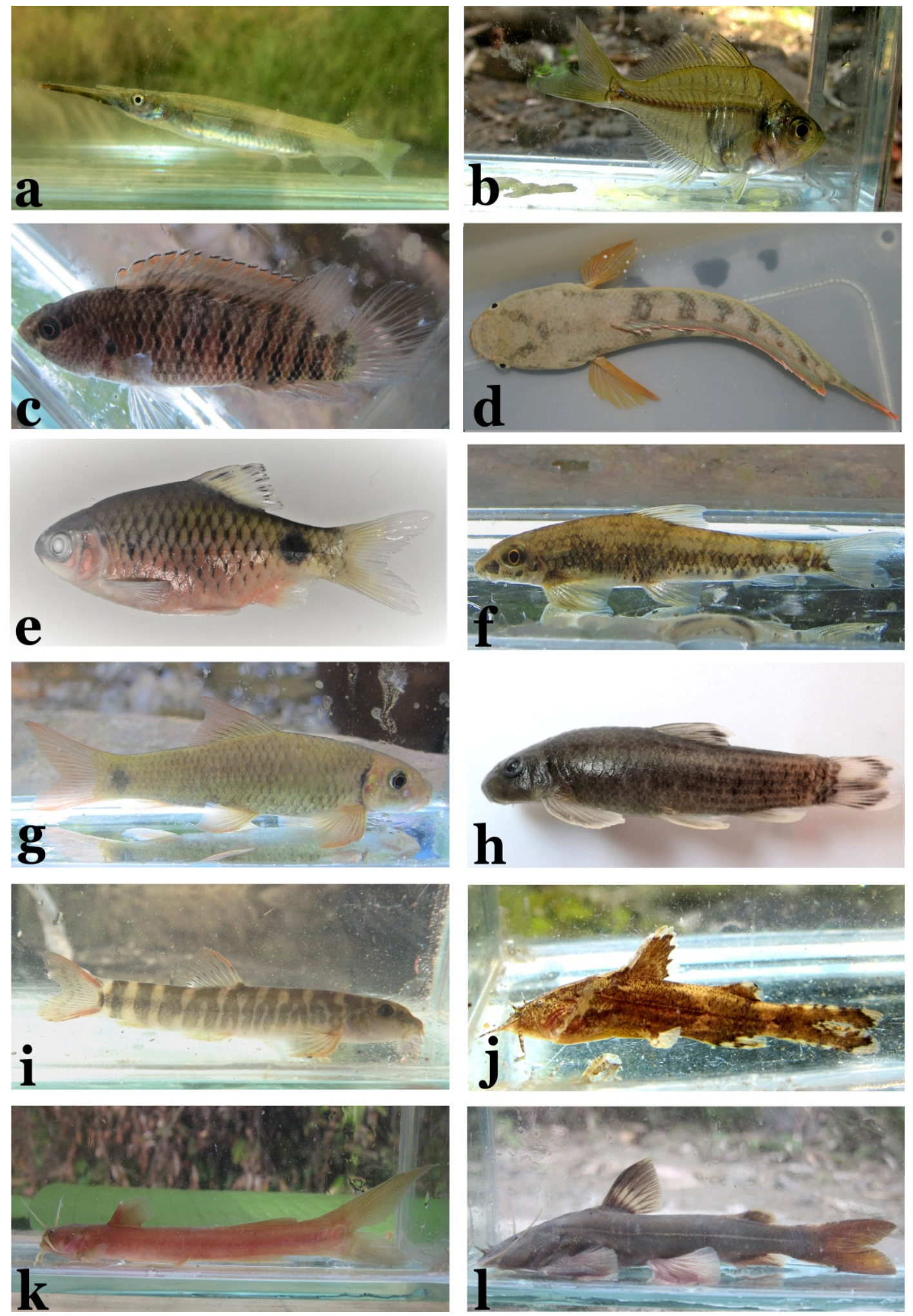

Fig. 2: Unique fish species of the Dampa Tiger Reserve, Mizoram, North-Eastern India. (a) Dermogenys sp. (b) Parambasis ranga (c) Badis rhabdotus d) Channa aurantipectoralis (e) Pethia rutila (f) Psilorhynchus rahmani (g) Garra nigricollis (h) Garra dampaensis (i) Schistura paucireticulata (j) Pseudolaguvia fucosa (k) Olyra sp. (l) Glyptothoraxsp. 
Remarks: Body deep and compressed. Labial groove interrupted. 2+ 8-9 gill rakers, dorsal fin with 9-10 branched rays and pectoral fin with 14 branched rays. 26-27 lateral line scales. A large black blotch on the caudal peduncle.

\section{Opsarius barna (Hamilton, 1822) \\ Common Name: Barnabaril \\ Local Name: Lengphar}

Remarks: Deep, compressed and elongate bodied fish. Barbel absent. Lateral line complete with $36-38$ scale rows. Body with 8-11 vertical bars on the side of the body.

\section{Pethia conchonius (Hamilton, 1822) \\ Common Name: Rosy barb \\ Local Name: Nghameidum}

Remarks: Broad infraorbital 3, absence of rostral barbels, minute or absent maxillary barbels, a stiff and serrated last unbranched dorsal fin ray, lateral line incomplete, presence of a black blotch on the caudal peduncle. Dorsal fin edged with black marking. $5^{\text {th }}$ ceratobranchial broad, characterized by a pointed dorsal tip.

\section{Pethia rutila Lalramliana, Knight \& Laltlanhlua, 2014 Common Name: Barb Local Name: Nghameidum sen}

Remarks: It is a new species recently described from Aivapui and Keisalam Rivers of Dampa Tiger Reserve. It is characterized and diagnosed by having a complete lateral line, a black caudalpeduncle blotch extending over scales $16-18$ or $17-19$ of the lateral line centered above the insertion of the last anal-fin ray; an inconspicuous black humeral spot on the scale row below the $3 \mathrm{rd}$ and 4th lateral-line scales; 8 or 9 predorsal scales; $4 \frac{1}{2}$ scales between dorsal-fin origin and lateral line, and $3 \frac{1}{2}$ scales between lateral line and pelvic-fin origin.

\section{Puntius sophore (Hamilton, 1822) Common Name: Pool Barb Local Name: Nghameidum biangtai}

Remarks: Barbels absent; dorsal fin with 8 branched rays; anal fin with 5 branched rays; last unbranched dorsal-fin ray smooth and strong, lateral line complete, with 24-25 pored scales on the body; a post-epiphysial fontanelle present; infraorbital 3 slender and a colour pattern includes a (sometimes faint) black spot or blotch on the caudal peduncle. A smaller black blotch at base of dorsal-fin rays $5-7$.

\section{Rasbora daniconius (Hamilton, 1822)}

Common Name: Black line rasbora/ Slender rasbora Local Name: Nghadawl dung rin

Remarks: Body oblong and compressed. Barbels absent, 28-29 lateral line scales, almost or complete, with only last few scales lacking pores. Circumpeduncular scales 14. Body color olive on back, silvery on flanks and belly. Black stripe from eye to caudal fin.

Tor putitora (Hamilton, 1822)

Common Name: Golden mahseer

Local Name: Nghahrah

Remarks: Body deep and compressed. Labial groove continuous. $2+14$ gill rakers, dorsal fin with 9 branched rays, pectoral fin with 15 branched rays. $25-26$ lateral line scales.

\section{Family: Nemacheilidae Paracanthocobitis sp. \\ Common Name: Zipper loach \\ Local Name: Dawntial}

Remarks: Complete lateral line; axillary pelvic lobe absent; Dark spots along lateral line; 4-5 dark bands on caudal fin of adult; usually 11-12 dorsal-fin rays and 12-13 pectoral-fin rays.

\section{Schistura aff. fasciata Lokeshwor \& Vishwanath, 2011 Common Name: Stone loach Local Name: Dawntial}

Remarks: 11-13 dark brown transverse bars against pale yellow background on the body, moderately high adipose crest on dorsal and ventral sides of caudal peduncle; lateral line incomplete, reaching vertical to posterior end of anal fin base; three (sometimes only one) black spots on base of dorsal fin, dorsal fin with $8 \frac{1}{2}$ branched rays. The species is very similar to $S$. fasciata, however, it differs in presence (vs. absent in S. fasciata) of median notch on the lower jaw.

\section{Schistura paucireticulata Lokeshwor, Vishwanath \& Kosygin, 2013 \\ Common Name: Stone loach \\ Local Name: Dawntial}

Remarks: The species is characterized by having complete lateral line, 8-9 brown bars and saddles on body, saddles in front of dorsal fin dividing into 2-3 small bars forming reticulated appearance as they descend onto side of body; basi-caudal bar black, dissociated; dorsal fin spotted, with $81 / 2$ branched rays; caudal fin deeply emarginated with $9+8$ branched rays; welldeveloped axillary pelvic lobe and caudal fin with numerous black spots arranged in 3-4 bars.

\section{Family: Psilorhynchidae Psilorhynchus sucatio (Hamilton, 1822) \\ Common Name: River stone carp \\ Local Name: Lawngbal/Lungbal liak}

Remarks: It is characterized by the presence of anteriorly directed radii over the anterior field of body scales, rostral cap separate from the upper lip around the corner of the mouth and by the absence of a post-epiphyseal fontanelle, absence of the 
Table 1: Distribution of fish species in Dampa Tiger Reserve. ('+' indicates presence and '-'absence.)

\begin{tabular}{|c|c|c|c|c|c|c|}
\hline \multirow[t]{2}{*}{ Scientific name } & \multicolumn{6}{|c|}{ Habitat/Locality } \\
\hline & Teirei & Seling & Keisalam & Aivapui & Tut & Mar \\
\hline \multicolumn{7}{|l|}{$\begin{array}{l}\text { ORDER: BELONIFORMES } \\
\text { Family: Belonidae }\end{array}$} \\
\hline \multicolumn{6}{|l|}{ Family: Zenarchopteridae } & + \\
\hline $\begin{array}{l}\text { Dermogenys sp. } \\
\text { ORDER: CYPRINIFORMES } \\
\text { Family: Balitoridae }\end{array}$ & - & - & + & - & - & - \\
\hline $\begin{array}{l}\text { Balitora brucei } \\
\text { Family: Cobitidae }\end{array}$ & + & - & + & - & Family: Cobitidae & - \\
\hline \multicolumn{7}{|l|}{ Family: Cyprinidae } \\
\hline Amblypharyngodon mola & + & + & + & + & + & + \\
\hline Barilius bendelisis & + & - & - & - & + & - \\
\hline Devario aequipinnatus & + & + & + & + & + & + \\
\hline Danio dangila & + & + & + & + & + & + \\
\hline Esomus danricus & + & + & + & + & + & + \\
\hline Garra aff. lissorhynchus & + & - & - & - & + & - \\
\hline Garra dampaensis & - & + & + & + & - & - \\
\hline Garra manipurensis & + & + & + & + & + & + \\
\hline Garra nigricollis & - & + & + & + & - & - \\
\hline Garra sp. & + & - & - & - & + & - \\
\hline Neolissocheilus hexagonolepis & + & + & + & + & + & + \\
\hline Opsarius barna & + & - & - & - & + & - \\
\hline Pethia conchonius & + & - & - & - & + & - \\
\hline Pethia rutila & - & + & + & + & - & + \\
\hline Puntius sophore & + & + & + & + & + & + \\
\hline Rasbora daniconius & + & + & + & + & + & + \\
\hline Tor putitora & + & + & + & + & + & + \\
\hline \multicolumn{7}{|l|}{ Family: Nemacheilidae } \\
\hline Paracanthocobitis sp. & - & - & + & - & - & - \\
\hline Schistura aff. fasciata & + & + & + & + & + & + \\
\hline Schistura paucireticulata & + & + & + & + & + & + \\
\hline \multicolumn{7}{|l|}{ Family: Psilorhynchidae } \\
\hline Psilorhynchus sucatio & + & - & - & - & + & - \\
\hline Psilorhynchus nudithoracicus & + & - & - & - & + & - \\
\hline $\begin{array}{l}\text { Psilorhynchus rahmani } \\
\text { ORDER: MUGILIFORMES } \\
\text { Family: Mugilidae }\end{array}$ & - & + & + & + & - & + \\
\hline Rhinomugil corsula & - & - & - & - & + & - \\
\hline \multicolumn{7}{|l|}{ ORDER: PERCIFORMES } \\
\hline \multicolumn{7}{|l|}{ Family Badidae } \\
\hline Badis rhabdotus & - & + & + & + & - & + \\
\hline \multicolumn{7}{|l|}{ Family: Chandidae } \\
\hline Parambasis ranga & + & - & + & - & - & - \\
\hline \multicolumn{7}{|l|}{ Family: Channidae } \\
\hline Channa aurantipectoralis & - & + & + & - & - & - \\
\hline Channa marulius & - & - & + & - & + & - \\
\hline Channa gachua & + & + & + & + & + & + \\
\hline Channa punctata & + & + & + & + & + & + \\
\hline Family: Gobiidae & & & & & & \\
\hline Glossogobius giuris & + & + & + & + & + & + \\
\hline $\begin{array}{l}\text { ORDER: SILURIFORMES } \\
\text { Family: Amblycipitidae }\end{array}$ & & & & & & \\
\hline
\end{tabular}


Table 1: Distribution of fish species in Dampa Tiger Reserve. ('+' indicates presence and '-'absence.)

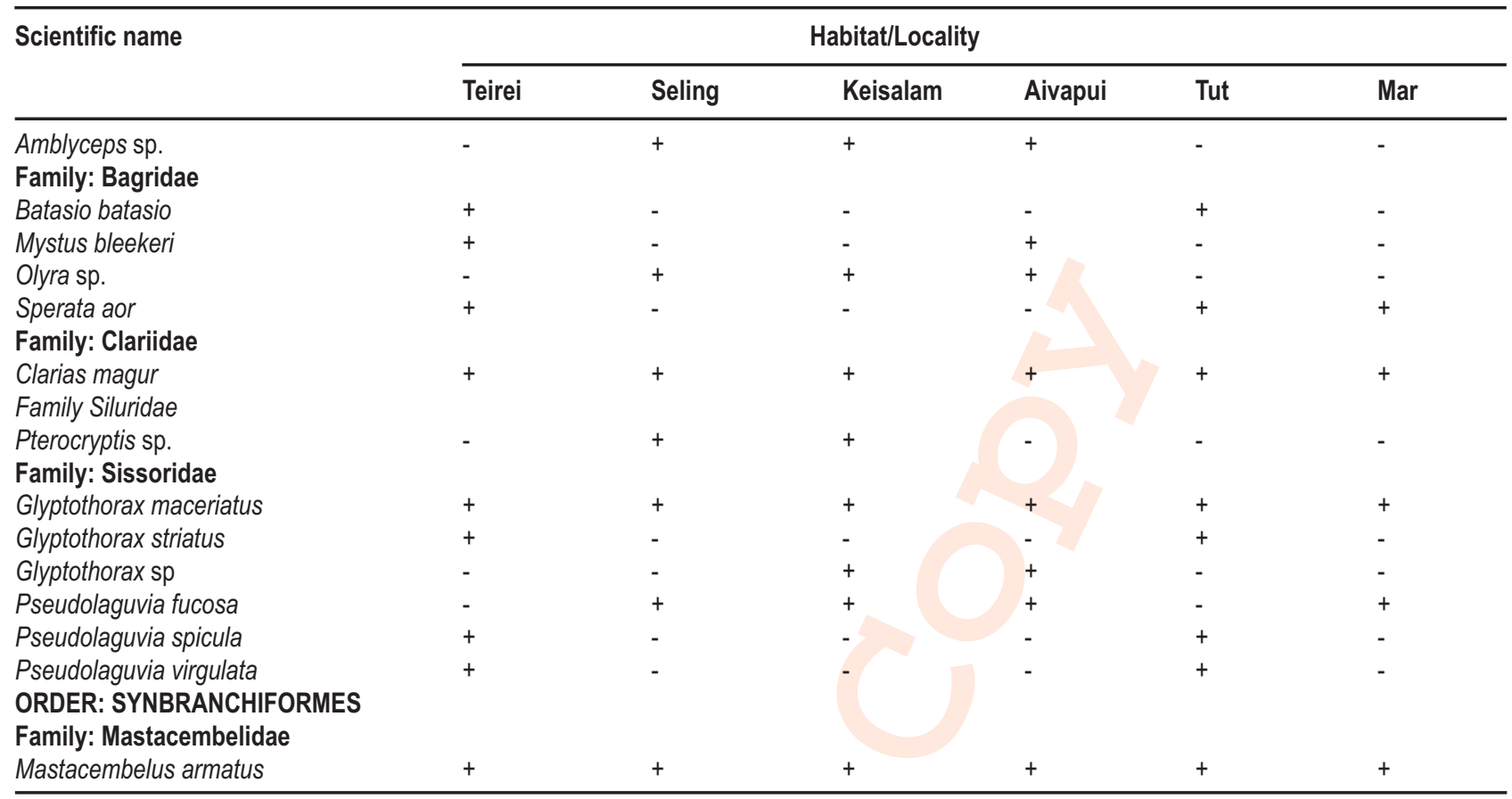

supraorbital bone, 8 branched dorsal-fin rays, 9+9 principal caudal-fin rays, 33-36 lateral line scales and 4-5 unbranched pectoral-fin rays.

\section{Psilorhynchus nudithoracicus Tilak \& Husain, 1980 Common Name: Rainbow minnow \\ Local Name: Lawngbal/Lungbal liak}

Remarks: It is characterized by large and flap-like skin folds at the lateral corner of the mouth, which extend further posteriorly than the lower jaw cushion, two dorsal saddles anterior to dorsal saddle positioned at dorsal-fin origin, irregular dark brown or black markings on the dorsal fin, $9-10+8-9$ principal caudal-fin rays, 32-34 lateral line scales.

\section{Psilorhynchus rahmani Conway \& Mayden, 2008}

Common Name: Rainbow minnow

Local Name: Lawngbal/Lungbal liak

Remarks: Psilorhynchus with shallow dorsal saddles extending 1-2 scale rows downwards from dorsal surface; arrange in a longitudinal row on the flank. Absence of dark vertical bars on the caudal fin and dark blotch on the distal edge of the dorsal fin. Postepiphysial fontanelle absent.

\section{ORDER: MUGILIFORMES}

Family: Mugilidae

Rhinomugil corsula (Hamilton, 1822)

Common Name: Corsula mullet

Local Name: Ngha mit lang
Remarks: Body sub-cylindrical anteriorly then compressed posteriorly. Head flat above and compressed at side. Two dorsal fins on the back. Scales ctenoid. Caudal fin slightly emarginated. First dorsal fin with 4 rays, second dorsal fin with 7-8 branched rays, pectoral fin with 15-16 rays, pelvic fin with 5 branched rays and anal fin with 9 branched rays.

\section{ORDER: PERCIFORMES}

\section{Family: Badidae}

Badis rhabdotus Kullander, Nóren, Rahman \& Mollah, 2019

Common Name: Dwarf Chameleon Fish

Local Name: Nghameihawl/Kawngkhawli Nu Themtleng

Remarks: No dark blotch dorso-laterally on the caudal peduncle; absence of a black blotch anteriorly on the dorsal fin and on the gill cover. Vertical bars usually curved. 28-29 vertebrae, 27-29 lateral scale row and XVI-XVII. 71/2-81/2 dorsal-fin rays

\section{Badis sp.}

Common Name: Dwarf Chameleon Fish

Local Name: Nghameihawl/ Kawngkhawli Nu Themtleng

Remarks: No dark blotch dorso-laterally on the caudal peduncle; absence of a black blotch anteriorly on the dorsal fin and on the gill cover. Vertical bars usually curved. 28-29 vertebrae, 27-29 lateral scale row and XVI-XVII. 71/2-81/2 dorsal-fin rays

\section{Family: Chandidae}

Parambassis ranga (Hamilton, 1822)

Common Name: Indian glassy fish 
Local Name: Ngha darthlalang/Ngha thing har

Remarks: It is characterized by presence of vertically humeral blotch. First dorsal fin with 7 spines, second one longest; second dorsal fin continuous with first with 1 spine and 14-15 branched rays. Anal fin with 3 spines, third one longest, with 14-15 branched rays. Pelvic fin with 1 spine and 5 branched rays. Pectoral fin with 10 rays.

\section{Family: Channidae}

Channa aurantipectoralis Lalhlimpuia, Lalronunga \& Lalramliana, 2016

Common Name: Bullseye Snakehead

Local Name: Nghavawk

Remarks: The species belongs to the Channa gachua species group (sensu Britz, 2008). It is unique in having uniformlycoloured bright-orange pectoral fins, lacking any spots, stripes or bands, and a dark V-shaped blotch on the dorsal surface of head in life. Absence of scales on the gular region, presence of a large scale on each side of the ventral surface of the lower jaw, 51-64 lateral-line scales, 34-37 dorsal-fin rays, 23-25 anal-fin rays, 13-14 pectoral-fin rays, $5 \frac{1}{2}-6 \frac{1}{2} / 1 / 71 / 2-81 / 2$ transverse scale rows.

\section{Channa marulius (Hamilton, 1822)}

Common Name: Bullseye Snakehead

Local Name: Nghakhing

Remarks: Channa with a large black occelus on upper caudal fin base. 4-5 large dark blotches on the side of the body and a distinct white spot scattered on the body and fins. Dorsal fin rays 50-55, anal fin rays 31-35, lateral line scales $60-70$ and lower jaws with no scales

\section{Channa gachua (Hamilton, 1822)}

Common Name: Dwarf snakehead

Local Name: Nghavawk

Remarks: A small sized Channa with $32-37$ dorsal fin rays, 39-48 lateral line scales, 15-17 pectoral fin rays and 21-27 anal fin rays. Maxillary and premaxillary processes extending to vertical through posterior rim of orbit, one or two large cycloid scales on each side undersurface of lower jaw.

\section{Channa punctata (Bloch, 1793)}

Common Name: Spotted snakehead

Local Name: Nghavawk/Nghakulram

Remarks: Channa with 4-6 scales on cheek, no dark bar across pectoral fins, lateral line scales 35-40, dorsal fin rays 28-32, anal fin rays 19-21. Sides of lower jaw with one large cycloid scale. A series of 8-9 vertical bars above lateral line.

\author{
Family: Gobiidae \\ Glossogobius giuris (Hamilton, 1822) \\ Common Name: Goby
}

Local Name: Nghalaiking

Remarks: Body elongated, cylindrical anteriorly and compressed posteriorly. Head depressed. Lower jaw longer than upper jaw. Pelvic fins united forming a sucking disc. Pectoral lightly spotted with 20-22 rays. Lateral line scales 32-34.

\section{ORDER: SILURIFORMES \\ Family: Amblycipitidae \\ Amblyceps sp. \\ Common Name: Torrent catfish \\ Local Name: Nghazangrek}

Remarks: Amblyceps with incomplete lateral line. Absence of projecting hook on proximal lepidotrichia of the median caudal-fin rays. Longer and slender compared to $A$. mangois. The posterior end of adipose fin closer to caudal fin base compared to $A$. arunachalensis.

\section{Family: Bagridae \\ Batasio batasio (Hamilton, 1822) \\ Common Name: Batasio \\ Local Name: Nghangiai te}

Remarks: The body color consisting of a horizontal stripe. Dorsal-fin spine with 16.0-18.5\% SL, straight, slender, posterior edge serrated. Body depth 17.0-17.4\% SL; adipose fin base $24.8-26.5 \%$ L. Barbels four pairs. Maxillary barbel extending to posterior border of eye. Nasal barbeldepressed at base. Outer mandibular barbel longer than inner. Inner mandibular barbel minute. Skin smooth. Lateral line complete, midlateral.

Mystus bleekeri(Day, 1877)

Common Name: Bleeker's Mystus

Local Name: Nghangiai te

Remarks: Median longitudinal groove on head shallow, reaching base of occipital process. Four pairs of barbells, maxillary pair reaching anal fin. Dorsal fin spine strong, smooth on both sides. Adipose dorsal fin immediately behind rayed dorsal fin. Pectoral fin spine strong and serrated along inner margin. Caudal-fin forked.

\section{Olyrasp.}

Common Name: Asian fighting catfish/Banner tail catfish Local Name: Nghakhuai dung tial/Nghazangrek dungtial

Remarks: Body slender and long. Strongly forked caudal fin; Adipose fin long. Distance between posterior base of dorsal fin and adipose fin longer than $\mathrm{O}$. longicaudata.

\section{Sperata aor (Hamilton, 1822)}

Common Name: Long whiskered catfish

Local Name: Nghangiai/nghalukawr sei

Remarks: Four pairs of barbels, maxillary pair very long. Dorsal fin spine strong, serrated posteriorly. Pectoral fin serrated along 
the inner margin. Lateral line complete. Posterior end of adipose fin with ovoid black spot.

\section{Family: Clariidae \\ Clarias magur (Hamilton, 1822) \\ Common Name: Magur \\ Local Name: Makur}

Remarks: Four pairs of barbels present, maxillary extending beyond base of pectoral fin Anterior profile of head ovoid when viewed dorsally; frontal fontanel long and thin. Anterior margin of pectoral spine serrated. Anal fin long, not confluent with caudal fin.

\section{Family: Sissoridae \\ Glyptothorax maceriatus Ng \& Lalramliana, 2012 \\ Common Name: Glypto \\ Local Name: Sarba}

Remarks: Nasal barbel not reaching anterior orbital margin; thoracic adhesive apparatus with narrow elliptic central depression that is almost wholly enclosed posteriorly by skin ridges (striae) and with single, non-diverging series of striae running along its edges; unculiferous ridges of adhesive apparatus not extending anteriorly onto gular region; absence of striae on first pectoral- and pelvic-fin elements; smooth posterior edge of dorsal spine.

\section{Glyptothorax striatus (McClelland, 1842) \\ Common Name: Glypto \\ Local Name: Sarba}

Remarks: Prominently plicate ventral surface of the pectoral-fin spine and the first pelvic-fin ray, plicae on pectoral-fin spine continuous, wedge-shaped central depression in thoracic adhesive apparatus devoid of skin ridges and distinct pale midlateral stripe on body

\section{Glyptothoraxsp.}

Common Name: Glypto

Local Name: Sarba

Remarks: Very similar to Glyptothorax scrobiculus. They are diagnosed in having a furrow running along the entire length of the ventral surface of the pectoral spine. Unculiferous ridges of thoracic adhesive apparatus not extending anteriorly onto gular region; absence of both dark saddles on body and dark crescentic mark at base of caudal fin.

\section{Pseudolaguvia fucosa Ng, Lalramliana \& Lalronunga, 2016 Common Name: Bee catfish/dwarf sissorid Local Name: Nghaberbek rang}

Remarks: The side of body with pale yellowish patches and irregular bands. The species can be distinguished from all other species except for $P$. virgulata in having (vs. lacking) a pale, Y- shaped marking on the dorsal surface of the head. However, the two species is differing in fin morphology where $P$. fucosa possessed more gently-sloping anterodorsal margin of the fin originating nearer to the base of the last dorsal-fin ray. Furthermore, the two species differs in having the posterior extent of the thoracic adhesive apparatus and the number of serrations on the anterior margin of the dorsal spine.

\section{Pseudolaguvia spicula Ng \& Lalramliana, 2010 \\ Common Name: Bee catfish/dwarf sissorid \\ Local Name: Nghaberbek rang}

Remarks: It possessed smooth anterior edge of dorsal-fin spine with its length 11.6-14.3\% SL which are the unique characters and differentiate the species from all other species belonging to the genus.

\section{Pseudolaguvia virgulata $\mathrm{Ng}$ \& Lalramliana, 2010 \\ Common Name: Bee catfish/dwarf sissorid Local Name: Nghaberbek}

Remarks: The species is characterized by having a series of two to three pale, narrow longitudinal stripes running along the sides of a brown body extending from the middle of the dorsal fin base to the middle of the caudal peduncle The presence of a pale, $Y$ shaped marking on the dorsal surface of the head is also unique to this species.

\section{ORDER: SYNBRANCHIFORMES \\ Family: Mastacembelidae \\ Mastacembelus armatus (Lacepède, 1800) \\ Common Name: Tyre track eel/ zig-zag eel \\ Local Name: Nghalerh}

Remarks: Body elongated, slender and slightly compressed. Long dorsal and anal fins confluent with caudal fin. Pelvic fin absent. Scales minute. Colour dark brown with zig-zag lines, ventral yellowish. Dorsal fin with 32 spines and 78-88 rays, anal fin with 3 unbranched and $77-86$ rays.

The essential foundation of species conservation includes assessment of the species diversity where accurate identification and their ecological studies of the species to be conserved is the primary step. Identification to the species level is always challenging especially among the cryptic species. The study revealed that the fish diversity in Dampa Tiger Reserve is dominated by the order Cypriniformes ( $50.0 \%$ of the total species) followed by order Siluriformes with $26.0 \%$ of the total species. The percentage wise contributions of different order (in descending order) are as follows: Cypriniformes (50.0\%), Siluriformes $(26.0 \%)$, Perciformes (16.0\%), Beloniformes (4\%), Mugiliformes $(2.0 \%)$ and Synbranchiformes (2.0\%).

As already mentioned, the rivers of Dampa Tiger Reserve is unique where the study resulted in the discovery of 2 new fish species (Lalramliana et al., 2014; Lalhlimpuia et al., 2016). 
Further the previously described new fish species (Lalronunga et al., 2013) from the Reserve, Garra dampaensis, was included among the collection. Apart from the new species, Badis rhabdotus and Psilorhynchus rahmani are recorded for the first time in India; the genus Dermogenys (half beak) is recorded for the first time in Mizoram and Garra nigricollis and Schistura paucireticulata are recorded for the first time in Karnaphuli drainage. Among the order Belinoformes, Xenentodon cancila is common and found in all the rivers surveyed whereas Dermogenys sp. is collected from the Keisalam River only. It is worth mentioning here that members of the freshwater halfbeak genus Dermogenys are hard to identify to the species level, due to morphometric and colour pattern differences (Farhana et al., 2018). The highly encountered order Cypriniformes is again dominated by the family Cyprinidae where Garra nigricollis is reported for the first time from the Karnaphuli drainage. Garra nigricollis is described from specimens of Taunggok Market, Rakhine State, Myanmar (the Rakhine Yoma) and had recently been recorded from the Kaladan drainage of Mizoram (Solo and Lalnuntluanga, 2018).

The specimens collected from the Dampa Tiger Reserve was first thought to belong to another species, since it belongs to totally different drainage system. However, in depth studies concluded that they are conspecific. It may be concluded that, though, belong to different drainage system, both the rivers flow into the Bay of Bengal where the mouths of Karnaphuli drainage and the west flowing streams of the Rakhine Yoma are very close to each other. Similar case was reported where some species of Rakhine Yoma extended to the adjacent river drainage, the Kaladan River (Nebeshwar and Vishwanath, 2017). Similarly, Schistura paucireticulata is recorded for the first time from the Karnaphuli drainage. The species is described from the Tuirial River (a tributary of Barak drainage) and this study being the first time where the species is recorded from a river system totally separated from the river where it was described. Further, Psilorhynchus rahmani, a species under the family Psilorhynchidae, as mentioned above, is reported for the first time from river of India. This is not surprising at all where the type specimens are collected from the same drainage, the Karnaphuli drainage in Bangladesh.

The order Perciformes, comprising the genera Badis, Parambasisis and Channa, usually fetch a high price value in ornamental business. The ornamental business, in general, are receiving increased attention due to the local and global demand and the consequent growth of the export market and trade (Sharma, 2020). The Badis sp. collected from the Teirei river, a tributary of Barak drainage cannot be identified to the species level due to morphological complications, however, Badis rhabdotus is a species recently described from Bangladesh, the neighbouring country, and this study form the first report of the species from India. Channa aurantipectoralis, a new species described from the Reserve (Lalhlimpuia et al., 2016), along with C. gachua belongs to 'Channa gachua species group', a group of species characterized by a varying number of dark and light semi-circular bands on the pectoral fin beside other characters. Surprisingly, $C$. aurantipectoralis is distinct from all other group members in lacking any marking on the pectoral fin, however, it is still included among the groups because of other morphological resemblance.

Among the order Siluriformes, Amblyceps sp., Glyptothorax sp., Olyra sp. and Pterocryptis sp. cannot be identified to the species level. The Amblyceps sp. is very similar to both $A$. mangois and $A$. arunachalensis, however, it is long and slender compared to $A$. mangois and the adipose fin to caudal fin base distance is longer compared to $A$. arunachalensis. Therefore, we refrain from assigning the name until DNA proof is available. Similarly, the Glyptothorax sp. is very similar to G. scrobiculus, a species described from the Barak drainage system, in overall morphological aspects, however, differed in their osteology. Further, the Olyra sp. encountered in this study closely resemble 0 . longicaudata in having a long adipose fin, however, the distance between posterior base of dorsal fin and adipose fin is longer than O. longicaudata. The genera Garra, Xenentodon, Neolissochilus, Tor, Schistura and Mastacembelus etc. showed widespread distribution, whereas those fish belonging to family sissoridae remain restricted. The result is in concordance with the statement that the rheophilic species are restricted to a particular region due to high habitat specificity ( $\mathrm{Ng}$ and Rachmatika, 2005).

In conclusion, the high diversity observed in this study revealed the importance of the Dampa Tiger Reserve and may act as 'gene source' to the area diversity. The protected areas and the community fish habitat protection areas not only play an important role in protecting rare and vulnerable species, but also provide and establish the area for research and future biodiversity monitoring.

\section{Acknowledgments}

We gratefully acknowledge the research grant sanctioned by DST-SERB (No. EEQ/2018/000805; Dt. 23.05.2019). We are thankful to Mr Laltlanhlua Zathang, Director Dampa Tiger Reserve for the research permit (No. B. 15011/8/2010-PT (D)) granted to carry out this study; Forest staffs of Dampa Tiger Reserve for their support; Vanlalmalsawma, Zakhuma and James L Hrahsel for their field assistance; Dr Tawnenga, Principal, Pachhunga University College for providing laboratory facilities.

\section{References}

Britz, R.: Channa ornatipinnis and C. pulchra: Two new species of dwarf snakeheads from Myanmar (Teleostei: Channidae). Ichthyol. Explor. Fres., 8 (for 2007), 335-344 (2008).

Champion, H.G. and S.K. Seth: A Revised Survey of the Forest Types of India. Published by Govt. of India, New Delhi (1968).

Farhana, S.N., Z.A. Muchlisin, T.Y. Duong, S. Tanyaros, L. M. Page, Y. Zhao, E.A.S. Adamson, M.Z. Khaironizam, M. de Bruyn and M.N.S. Azizah: Exploring hidden diversity in Southeast Asia's Dermogenys spp. (Beloniformes: Zenarchopteridae) through DNA barcoding. Sci. Rep., 8, 10787 (2018). 
Jayaram, K.C.: The freshwater fishes of the Indian region. Narendra Publishing House, New Delhi, India (1999)

Jayaram, K.C.: Catfishes of India. Narendra Publishing House. New Delhi, India (2006).

Kottelat, M.: Indochinese Nemacheilines: A revision of nemacheiline loaches (Pisces: Cypriniformes) of Thailand, Burma, Laos, Cambodia and Southern Vietnam. Pfeil, München (1990).

Lalhlimpuia, D.V., S. Lalronunga and Lalramliana: Channa aurantipectoralis, a new species of snakehead from Mizoram, North-eastern India (Teleostei: Channidae). Zootaxa, 4147, 343-350 (2016).

Lalramliana., J.D.M. Knight and Z. Laltlanhlua: Pethia rutila (Teleostei: Cyprinidae), a new species from Mizoram, North-east India. Zootaxa, 3827, 366-374 (2014).

Lalronunga, S., Lalnuntluanga and Lalramliana: Garra dampaensis, a new ray-finned fish species (Cypriniformes: Cyprinidae) from Mizoram, North-eastern India. J. Threat. Tax., 5, 4368-4377 (2013).

Menon, A.G.K.: Monograph of the cyprinid fishes of the genus Garra Hamilton. Mem. Indian Mus., 14, 173-260 (1964).

Nebeshwar, K. and W. Vishwanath: On the snout and oromandibular morphology of genus Garra, description of two new species from the Koladyne River basin in Mizoram, India, and re-description of
G. manipurensis (Teleostei: Cyprinidae). Ichthyol. Explor. Fres., 28,17-53 (2017).

Ng, H.H. and I. Rachmatika: Glyptothorax exodon, a new species of rheophilic catfish from Borneo (Teleostei: Sisoridae). Raffles Bull. Zool., 53, 251-255 (2005).

Pawar, S. and A. Birand: A Survey of Amphibians, Reptiles and Birds in Northeast India. CERC Technical Report \#6, Centre for Ecological Research and Conservation, Mysore (2001).

Sharma, M.: Ornamental fish rearing and breeding - a new dimension to aquaculture entrepreneurship in Himachal Pradesh. Int. J. Fish. Aquat. Stud., 8, 157-162 (2020).

Smith, R. J., R.D.J. Muir, M.J. Walpole, A. Balmford and N. LeaderWilliams: Governance and the loss of biodiversity. Nature, 426, 67-70 (2003).

Solo, B. and Lalnuntluanga: Diversity, distribution and conservation status of fish of the genus Garra (Cypriniformes: Cyprinidae) from the Kaladan drainage of Mizoram, north-eastern India. Sci. Vis., 18, 125-132(2018).

Taylor, W.R. and G.G. Van Dyke: Revised procedures for staining and clearing small fishes and other vertebrates for bone and cartilage study. Cybium, 9, 107-119 (1985). 